\title{
REVISTAMARACANAN
}

Dossiê

\section{Fazendo divisas em terrenos alheios: um estudo preliminar sobre posse, propriedade da terra e conflitos em intendências municipais no Pará entre fins do século XIX e início do $\mathrm{XX}$}

\begin{abstract}
Making foreign currency on land: a preliminary study on land tenure, land ownership, and conflicts in municipal intendancies in Pará between the late 19th and early 20th centuries
\end{abstract}

Carlos Leandro Esteves*

Universidade Federal do Pará Cametá, Pará, Brasil

Recebido em: 15 ago. 2019.

Aprovado em: 10 dez. 2019.

\footnotetext{
* Professor Adjunto da Faculdade de História da Universidade Federal do Pará, Campus Cametá-Tocantis. Professor do Mestrado Profissional em Ensino de História da Universidade Federal do Pará, Campus Ananindeua. Doutor e Mestre em História Social pela Universidade Federal Fluminense; graduado em História pela mesma instituição. (carlean2005@uol.com.br)

ORCID iD: https://orcid.org/0000-0003-4685-8216

CV Lattes: http://lattes.cnpq.br/6758802097773377
} 


\title{
Resumo
}

O Presente artigo tem por objetivo realizar um debate acerca da intensificação dos conflitos por terra no Pará nas primeiras décadas da República. Pretende-se demonstrar que grande parte das disputas por lotes de terras esteve vinculada a denúncias de sobreposição de títulos de posse registrados nas intendências municipais por iniciativa de grandes posseiros, fazendeiros, comerciantes e herdeiros de sesmaria, que agiram como verdadeiros potentados locais em áreas há décadas apossadas por famílias de pequenos posseiros. Trata-se de apontar para uma mudança significativa ocorrida já nos anos iniciais da República: a atribuição dada às câmaras municipais de decidir acerca da questão das terras pertencentes ao seu patrimônio municipal. A análise empreendida busca compreender as relações entre práticas de propriedade, suas múltiplas interpretações à luz das mudanças e continuidades verificadas na passagem do Império para a República no Pará de fins do século XIX, e as ações de pequenos lavradores-posseiros com vistas a assegurar seu direito a permanecer nos lotes de terras onde mantinham posse. Tendo como horizonte teórico-metodológico a realização de uma história social da propriedade, as questões formuladas enquanto problemática de pesquisa foram dirigidas ao cotejamento de um corpus variado de fontes, dentre as quais se destacam: decretos e leis estaduais, notícias e artigos publicados na imprensa, carta de sesmaria, bem como protestos, contraprotestos e abaixo-assinados reproduzidos nas páginas dos jornais do período.

Palavras-chave: Propriedade. Posseiros. Intendências Municipais. Pará Republicano.

\begin{abstract}
The present article aims to hold a debate about the intensification of land conflicts in Pará in the first decades of the Republic. It is intended to demonstrate that a large part of the land disputes were linked to the overlapping of tenure titles registered in municipal intendancies on the initiative of large landowners, farmers, merchants and heirs of sesmaria, acted as real local potentates in areas for decades held by families of small squatters. This is to point to a significant change that occurred in the early years of the Republic: the attribution given to the municipal councils to decide on the question of the lands belonging to their municipal patrimony. The analysis sought to understand the relations between property practices, their multiple interpretations in the light of the changes and continuities verified in the passage from the Empire to the Republic in the late nineteenth-century Pará, and the actions of small peasants-squatters with a view to ensuring their right to remain on lots of land where they held possession. Having as a theoretical-methodological horizon the realization of a social history of property, the questions formulated as a research problem were directed to the collation of a varied corpus of sources, among which are highlighted: state decrees and laws, news and articles published in the press, sesmaria letter, as well as protests, counter-protests and undersigned reproduced on the pages of the newspapers of the period.
\end{abstract}

Keywords: Property. Squatters. Municipal Intendences. Republican Pará. 
Assim como sou submisso a autoridade, quando ela gira na esfera traçada pela mesma lei sei também reagir e não me deixar oprimir, repelindo a violência com violência.

Vicente de Souza Pinto, lavrador.

\section{Considerações iniciais}

Posseiros, foreiros, pequenos lavradores em geral, dedicados ao cultivo combinado de roças de subsistência a atividades extrativas de pequena escala, ocupantes há décadas em áreas que seriam palco de inúmeras querelas por direitos de propriedade, têm merecido pouca atenção da historiografia que se dedica aos estudos sobre o rural no Pará oitocentista. Nos últimos anos, tem havido um inequívoco predomínio de abordagens que rediscutem os espaços dos núcleos coloniais criados ainda no Império e continuados nas primeiras décadas da República, resultando em pesquisas basilares que apontam as colônias como locais de realização de projetos para onde convergiam o controle do território pela fixação do lavrador nos lotes estatais e a sua disciplinarização visando à produção agrícola destinada ao abastecimento de mercados próximos e sobretudo da capital. ${ }^{1}$

Não obstante tenham construído relevante contraste a abordagens que, fazendo coro às queixas de autoridades paraenses, reiteravam a ausência de mão de obra para a lavoura e uma crise na agricultura de gêneros em face da "fuga" de lavradores pela busca do lucro "fácil" proporcionado pela extração da borracha, reproduzindo, portanto, a lógica da dicotomia lavoura $x$ extrativismo, tais estudos não lograram até aqui dar conta de lançar luz sobre significativa parcela de pequenos lavradores, muitos dos quais chamados pejorativamente de "roceiros", ocupando há décadas terras havidas por apossamento. Esses homens e mulheres, posseiros de longa data, e que aqui pretendemos abordar, não se encontravam nem entre migrantes estrangeiros e nacionais, cujo destino eram os núcleos coloniais, nem entre os milhares de seringueiros que, em sua imensa maioria vindos de estados do Nordeste, sobretudo o Ceará, aventuraram-se em estradas de seringa localizadas nos cantos mais recônditos da Amazônia a partir da segunda metade do século XIX, em pleno período de boom da produção da borracha e de sua venda no mercado internacional.

Nosso objetivo no presente texto será o de compreender como por meio de queixas e denúncias expressas em "protestos, contra protestos, cartas e abaixo-assinados" endereçadas

\footnotetext{
${ }^{1}$ Dentre os trabalhos, destacamos: LACERDA, Franciane Gama. Migrantes cearenses no Pará: faces da sobrevivência (1889-1916). Belém: Açaí, 2010; NUNES, Francivaldo Alves. Terras de Colonização: agricultura e vida rural ao Norte do Império brasileiro. São Paulo: Scortecci, 2016; SANTOS, Francisnaldo Souza dos. Ações colonizadoras em descompasso: legislação, propaganda e atuação de colonos estrangeiros nos últimos anos do Império e início da República. 2016. Dissertação (Mestrado em História Social da Amazônia) - Faculdade de História, Universidade Federal do Pará, Belém.
} 
a autoridades municipais e estaduais e ao público em geral, ${ }^{2}$ a população pobre rural residente em lotes localizados na circunscrição dos patrimônios cedidos pelo Governo do Estado às intendências municipais, ${ }^{3}$ reivindicaram e pressionaram por direitos de propriedade em fins do século XIX e início do XX no Pará. No intuito de garantir a permanência nas posses que ocupavam há décadas contra cotidianas ameaças de expulsão e perda de direitos por poderosos locais num momento de acirramento de conflitos ocasionados tanto pelas mudanças ocorridas no âmbito da legislação estadual de terras quanto da expansão de domínios em áreas cobiçadas para a exploração da borracha, dentre outras motivações, vários posseiros em diferentes municípios do estado fizeram uso de queixas e denúncias que seriam recorrentemente publicadas em jornais da capital.

O presente artigo, resultado parcial de pesquisa em curso, pretende demonstrar que posseiros, lavradores pobres de várias regiões do estado, ao protagonizarem inúmeras querelas por direitos de propriedade fizeram uso de estratégias de ação que consistiam em tornar públicas denúncias contra ameaças que punham em risco a perspectiva de continuarem em suas posses, tanto nos casos em que já possuíam títulos de posse, quanto nos casos em que ainda precisavam fazer a declaração, medição e demarcação para obtê-los, conforme legislação vigente a partir de 1892 que tornava obrigatório o registro de lotes particulares localizados nas circunscrições dos patrimônios municipais das intendências.

Trata-se de "ouvir" homens e mulheres que com suas ações lograram participar diretamente em disputas e conflitos locais que realçavam a fragilidade do equilíbrio de forças no âmbito das municipalidades onde proprietários de terras, comerciantes, donos de seringais, intendentes, juízes, subdelegados e agrimensores, agiam por vezes em acordo para aproveitar-se das indefinições quanto aos limites dos lotes de terras num momento em que a Constituição estadual atribuía às municipalidades o poder de fazer medir e demarcar áreas ditas devolutas, assim como o de conceder títulos de posse e aforamento em terras pertencentes aos seus patrimônios municipais. ${ }^{4}$

Contudo, sem desconhecer a relevância de abordagens de síntese que procuram dar conta de um olhar panorâmico sobre a situação agrária do Pará no período, entendemos que a

\footnotetext{
2 Trata-se de levantamento por nós realizado por meio de pesquisa em jornais paraenses de fins do século XIX e início do XX. Nas páginas dos periódicos O Pará, O Liberal do Pará, Folha do Norte, O Democrata, A República e o Correio Paraense, pudemos acompanhar a recorrente publicação de abaixoassinados, cartas, protestos e contraprotestos originados de queixas e denúncias de pequenos posseiros contra ameaças de perda das posses bem como de violências cometidas a mando de grandes posseiros, fazendeiros, comerciantes e agentes públicos atuantes no âmbito das intendências municipais no decurso da primeira década da República. Esses jornais estão microfilmados e se encontram disponíveis para consulta no acervo da Biblioteca Arthur Vianna da Fundação Cultural do Estado do Pará - Centur. Contudo, para a elaboração deste artigo, realizamos consulta no site da Hemeroteca Digital da Biblioteca Nacional, onde os mesmos periódicos estão digitalizados. Disponível em: http://bndigital.bn.gov.br/hemeroteca-digital/.

3 Diferentemente de outros municípios da Federação, onde "Intendente" era o termo designado para nomear os membros dos Conselhos Municipais, como era o caso à época do DF, Rio de Janeiro, no Estado do Pará esse papel era desempenhado por "vogaes", enquanto o cargo de "Intendente Municipal" equivalia ao de Prefeito em outros estados.

4 No Estado do Pará, a partir de 1891, os cargos de delegado e subdelegado passarão a denominar-se como prefeito e subprefeito. Tais postos eram ocupados por chefias militares.
} 
escala de observação que segundo nossos objetivos melhor permite delinear as ações dos posseiros na prática de uma política cotidiana de protestos, queixas e defesa de direitos de propriedade se dá no âmbito da municipalidade. Questão que ainda carece de estudos aprofundados, o papel desempenhado pelas intendências e conselhos municipais no Pará em relação à regulamentação das formas de ocupação e acesso a terras pertencentes aos seus patrimônios municipais durante as primeiras décadas da República requer uma discussão acerca dos limites e atribuições dos municípios na nova configuração federalista inaugurada pelos governos republicanos.

Surgida de legislação estadual aprovada sob o espírito federalista no alvorecer da República, a prerrogativa de que seriam atribuídos aos municípios os trabalhos de medir, demarcar e reconhecer lotes de terras em posse de lavradores localizados nos limites patrimoniais das intendências mediante concessões de registros de posse seria, a nosso ver, uma das principais causas de disputas de terras durante os primeiros governos republicanos no Pará na medida em que ocorreram inúmeras expedições de títulos por parte das intendências para novos pretensos ocupantes em áreas há décadas apossadas por famílias de posseiros, dentre as quais muitas não detinham nenhum documento de posse.

Assim, podemos afirmar que entre a obrigatoriedade de declarar, medir e demarcar os lotes como condição para obter o registro da posse e a atribuição dada às intendências de controlar o acesso às terras no âmbito municipal, há a ocorrência de uma série de conflitos que desvelam sujeitos que pleiteiam direitos amparados pela certeza compartilhada em relação ao costume da posse engendrado por práticas proprietárias que tem no cultivo e beneficiamento da terra e no uso contínuo dos recursos o corolário do entendimento de justiça. ${ }^{5}$ Tudo isso num cenário que conjugava a expansão das áreas de seringais, projetos de modernização da agricultura de parte dos grandes proprietários e os esforços dos seguidos governos republicanos paraenses em promover por meio de leis e decretos uma normatização das formas jurídicas de propriedade.

Para dar conta dessa proposta, faremos inicialmente uma discussão que pretende abordar as implicações da nova legislação estadual quanto à municipalização da questão da terra, o que resultaria na autonomia atribuída aos municípios paraenses na gestão das terras pertencentes ao seu patrimônio, materializados na concessão de títulos de posse, na realização de demarcações, aforamentos e vendas de lotes a particulares, que passaram a vigorar no decurso das décadas de 1890 e 1900 em pleno acirramento dos debates sobre a federalização político-administrativa no Brasil republicano. Em seguida, discutiremos alguns casos de conflitos de terras protagonizados por posseiros paraenses em fins do século XIX em algumas intendências do Pará. Nosso objetivo aqui será observar as ações realizadas por pequenos

\footnotetext{
${ }^{5}$ A concessão de área que seria considerada como parte do patrimônio municipal foi regulada Lei n. 82 de 15 de setembro de 1892. Já a Lei n. 226 de 6 de julho de 1893 definia a autonomia e independência dos municípios no Pará. Ambas as leis versavam sobre a questão das terras devolutas no âmbito dos patrimônios municipais, a concessão de lotes a particulares, sua medição e discriminação, bem como o registro de posses ocupadas com "morada habitual e cultura efetiva". Ver: MUNIZ, João de Palma. Patrimônio dos Conselhos Municipais do Estado do Pará. Paris: Aillaud \& Cia., 1904.
} 
lavradores em face ao avanço sobre as terras onde há décadas mantinham posse. Trata-se, portanto, de acentuar a dinâmica das condições sociais dos conflitos que regulam o acesso à terra e aos recursos por diferentes grupos nas primeiras décadas dos governos republicanos paraenses.

Privilegiaremos aqui notícias e documentos publicados e reproduzidos nas páginas de inúmeros jornais paraenses do período. Assim como a documentação de origem judiciária permite divisar as estratégias mobilizadas pelos sujeitos querelantes num dado conflito, o uso da imprensa como fonte para a reconstrução de variadas contendas envolvendo posseiros tem se revelado importante instrumento para uma melhor compreensão e visibilidade desses sujeitos, posto que alguns jornais paraenses do período se constituíam em espaços de difusão de demandas da população pobre rural residente em áreas pertencentes aos patrimônios municipais. Dada a natureza desse tipo de fonte, essa abordagem permite-nos dar conta da cotidianidade das disputas e das relações sociais conflituosas em torno das novas definições em disputa acerca da posse e da propriedade da terra.

\section{Intendências e posse da terra no Pará nos primeiros governos republicanos: municipalismo e a questão dos patrimônios municipais}

A temática dos conflitos por direitos de propriedade quando considerada nos marcos das disputas locais do período inicial da República remete-nos para o papel das intendências municipais e a relevância política dos municípios no quadro do federalismo da primeira década republicana no Pará. Trata-se aqui de considerarmos os conflitos oriundos das ações de registros de terras e concessões de títulos de posse, das inúmeras denúncias de demarcações que, segundo os pequenos posseiros, estariam previamente sendo realizadas nos gabinetes das intendências, sem a devida medição, testemunho e conhecimento de moradores das áreas demarcadas. Pelo que pudemos verificar, tais ações ensejavam tentativas de favorecimento a grandes posseiros e comerciantes em detrimento dos pequenos a partir da perspectiva de conversão da "simples posse" numa dada forma de propriedade da terra presente nas ações das novas intendências municipais, cujo âmbito de atuação no que tange à questão do ordenamento do acesso às terras de seu patrimônio municipal buscava realizar-se em sintonia com os princípios federativos em voga, o que no caso do Pará, como veremos, ganharia significativa relevância.

O debate sobre a descentralização político-administrativa no Brasil e o papel das municipalidades encampado pelo movimento federalista no processo de construção da República em fins do século XIX destaca a influência exercida pelo modelo de federalismo adotado nos Estados Unidos e as dificuldades encontradas pela recém-inaugurada República brasileira em face da diversidade regional e dos frágeis vínculos entre as novas unidades 
federativas. ${ }^{6}$ Diferentes autores tem se debruçado criticamente sobre a questão da centralização político-administrativa vigente durante o Império, onde a ênfase dada durante muito tempo por uma historiografia consagrada reiterava o enfoque de que as Províncias eram administradas a partir de uma busca pela consolidação de um modelo que primava pela manutenção da unidade territorial ante as inúmeras tentativas de ruptura empreendidas em diferentes áreas do vasto território. ${ }^{7}$ Concebido dessa forma, havia pouco espaço no debate para se considerar as particularidades das disputas ocorridas no âmbito das províncias e consequentemente das municipalidades.

Nas últimas décadas, contudo, tem crescido o número de trabalhos que buscam superar as perspectivas inauguradas pelas abordagens "centralistas" e em seu lugar surge um conjunto vigoroso de reflexões que, ao contrário, procuram deslindar a tessitura das relações de poder e disputas em âmbito local. ${ }^{8} \mathrm{O}$ resultado tem sido a vinda a lume de estudos que destacam o papel das câmaras municipais durante o Império, relegada nos estudos anteriores à condição de subordinação e invisibilidade em relação às Províncias, bem como de trabalhos que abordam as ações e representações populares na esfera municipal no decurso da Primeira República, aspectos que ajudam a redimensionar as relações políticas entre grupos sociais e os poderes locais. Tais estudos tem destacado a importância de se considerar, no entrecruzamento das mudanças políticas ocorridas com o advento da República, a existência de uma multiplicidade de lutas "miúdas" por definições e exercícios de uma cidadania cotidiana e que eram protagonizadas por setores populares, sobretudo urbanos, que ia muito além da participação dos espaços restritos da política eleitoral reservados aos grupos dominantes tradicionais.

Quando consideramos a questão da municipalidade sob a ótica da Constituição da República dos Estados Unidos do Brasil, aprovada em 1891, devemos observar que já em seu artigo 68 a Carta demonstrava certa imprecisão quanto às atribuições municipais no novo quadro federativo, fruto de disputa entre defensores de uma maior autonomia dos entes munícipes e aqueles que mesmo pregando o federalismo entendiam que todo o âmbito decisório deveria manter-se na Unidade Federativa representada pelos Estados. Ao definir a autonomia dos municípios indicando que esta dar-se-ia em consonância com o "peculiar interesse" de cada Unidade Federativa, o texto constitucional deixava em aberto aos estados a possibilidade de estender o princípio federativo transpondo sua relação com a União para sua

\footnotetext{
${ }^{6}$ SANTIN, Janaína Rigo; RODIGHERI, Bruno Nogueira. O poder local na federação brasileira. Argumenta Journal Law, Jacarezinho (PR), n. 25, p. 275-299, jul.-dez. 2016.

7 Para uma revisão dessa perspectiva, ver: DOLHNIKOFF, Miriam. O pacto imperial: origens do federalismo no Brasil do Século XIX. São Paulo: Globo, 2005.

${ }^{8}$ Para um aprofundamento desse debate, recomendamos a coletânea: TERRA, Paulo Cruz; MAGALHÃES, Marcelo de Souza; ABREU, Martha (orgs.). Os poderes municipais e a cidade: Império e República. Rio de Janeiro: Mauad X, 2019.
} 
relação com os municípios, promovendo assim uma espécie de "subfederação dos municípios", segundo o estudo clássico de Vitor Nunes Leal. $^{9}$

Quanto à questão das terras, a historiografia tem destacado como o texto constitucional aprovado, sobretudo em seu artigo 90, evidenciou "a onipresença dos grandes proprietários de terras e seus aliados políticos", ${ }^{10}$ numa referência direta às atribuições concernentes aos estados da Federação de legislar sobre questões como a criação de impostos sobre exportação de mercadorias produzidas em suas circunscrições, bem como imposto sobre vendas de imóveis rurais e urbanos e transmissão de propriedade. Mudança significativa, contudo, residiria na questão das terras devolutas, cuja competência quanto à elaboração de legislação própria dada a cada Unidade Federativa, materializava o princípio da autonomia dos estados em face da União num tema que consagrava o poder das frações dominantes rurais ante um cenário em que as economias regionais se alicerçavam sobre bases eminentemente agrícolas.

É com esse espírito que o artigo 64 da Constituição determinava que: "Pertencem aos Estados as minas e terras devolutas situadas em seus respectivos territórios, cabendo à União somente a porção do território que for indispensável para a defesa das fronteiras, fortificações, construções militares e estradas de ferro federais." ${ }^{11}$

Caberia, portanto, aos estados legislar sobre o acesso a terras públicas, bem como promover o desenvolvimento de suas agriculturas em consonância com a premissa de um ideal de ruralismo capitaneado pelos interesses de frações dos setores dominantes rurais dedicadas, seja à pauta exportadora das grandes monoculturas, seja daqueles setores que, em oposição, defendiam o fortalecimento de uma produção agrícola destinada ao atendimento do mercado interno. ${ }^{12}$

Em decorrência das novas diretrizes republicanas sobre a questão da terra previstas na Constituição Federal de 1891 e na Constituição do Estado do Pará, aprovada no mesmo ano, ${ }^{13}$ foram elaborados no decurso dos anos seguintes uma serie de decretos e leis estaduais que

${ }^{9}$ LEAL, Vitor Nunes. Coronelismo, enxada e voto. O município e o regime representativo no Brasil. São Paulo: Companhia das Letras, 2012.

${ }^{10}$ ARRUDA, Pedro Fassoni. Capitalismo dependente e relações de poder no Brasil: 1889-1930. São Paulo: Expressão Popular, 2012, p. 289.

11 Disponível em: https://www2.camara.leg.br/legin/fed/consti/1824-1899/constituicao-35081-24fevereiro-1891-532699-publicacaooriginal-15017-pl.html. Acesso em: 13 jun. 2019.

12 As historiadoras Márcia Motta e Sônia Mendonça chamam a atenção para o fato de que nem todos os republicanos compactuavam com a ideia da transferência aos estados da competência de legislar sobre terras devolutas. Segundo as autoras, "Ao contrário, muitos acreditaram que os problemas relacionados a terras devolutas - sobretudo sua discriminação e demarcação - deveriam continuar, tal como durante o Império, a cargo do governo central." Cf.: MOTTA, Márcia M. M.; MENDONÇA, Sônia Regina de. Continuidade nas rupturas: legislação agrária e trabalhadores rurais no Brasil de inícios da República. Revista Brasiliense de Pós-graduação em Ciências Sociais, Brasília, v. VI, p. 127-147, 2002. Essa não parece ter sido a posição dos representantes do Pará no Congresso Constituinte. Ao contrário, é de autoria da representação paraense a supressão de restrições presentes no art. 64, garantindo assim a aprovação de que caberia aos Estados a propriedade das terras devolutas. Ver o "Discurso pronunciado pelo sr. Nina Ribeiro, em 9 de janeiro de 1891", publicado no jornal: A República, Belém, 10 jan. 1891, p. 2. Disponível em: http://memoria.bn.br/DocReader/704440/2691. Acesso em: 21 jul. 2019.

${ }^{13}$ A Constituição do Estado do Pará foi promulgada em 22 de junho de 1891. Nela, foi garantida a autonomia dos municípios que passariam a ser administrados por um Intendente e por um Conselho municipal composto por vogais. O Decreto estadual n. 385, de 8 de agosto de 1891, regularia a primeira eleição para Intendente e para o Conselho Municipal. 
regulavam questões acerca da medição, demarcação e revalidação de posses e antigas sesmarias, a normatização do acesso às terras públicas e questões referentes à separação entre terras públicas e privadas, questões já regidas por lei imperial, mas que agora ganhavam formalmente contornos locais em face do princípio federalista do novo regime.

Sobre o art. 64 da Constituição Federal, o então governador do Pará Lauro Sodré (18911897), em mensagem à Assembleia Legislativa em julho de $1892,{ }^{14}$ observava que a atribuição dada aos estados quanto à gestão das suas terras devolutas havia sido materializada "entre nós" no Decreto estadual n. 410 de 30 de outubro de $1891 .{ }^{15}$ Sobre a reserva de terras devolutas, o referido decreto trazia na redação de seu art. 19 que teriam esse destino àquelas terras "julgadas necessárias para a fundação de colônias, povoações, patrimônios de intendências, abertura de estradas, cortes de madeiras de construção naval e quaisquer servidões publicas". ${ }^{16}$

Em decorrência dessa prerrogativa, já em 1892, a Lei n. 82 de 15 de setembro, em seu art. 29, determinava: "Dentro de uma zona de $3 \mathrm{~km}$ em torno da sede de cada um dos atuais municípios, serão reservados nas áreas devolutas existentes, até 4.356 ha. para serem constituídos em patrimônio dos respectivos conselhos municipais, que os farão medir e discriminar por sua conta". ${ }^{17}$

No Pará, o princípio do federalismo e sua extensão para a relação entre o estado e os municípios conheceu uma conjuntura favorável materializada em leis que atribuíram às instâncias municipais, aos conselhos e intendentes, uma serie de prerrogativas que primavam pela autonomia municipal, sobretudo no que dizia respeito aos cuidados com o controle e organização do acesso às terras que passariam a fazer parte de seus patrimônios concedidos pelo Estado. A partir da Lei n. 226 de 6 de julho de 1893, os municípios paraenses passaram a ser reconhecidos, de acordo com o que consta em seu art. $1^{\circ}$, como "pessoas jurídicas, autônomas e independentes" na resolução e gestão dos interesses pertinentes ao seu patrimônio, o que incluía "Terras devolutas ou outros próprios do Estado quando sejam necessários ao município", ${ }^{18}$ conforme determinava o art. $7^{\circ}$ da referida lei.

Defensor incansável da medida e crítico ferrenho do "centralismo" dos tempos do Império, ocasiões em que não economizava nas tintas para exaltar os governos republicanos estaduais, sobretudo o Governo Augusto Montenegro (1901-1908) onde trabalhou como Chefe

14 PARÁ. Mensagem dirigida pelo Sr. Governador Lauro Sodré ao Congresso do Estado do Pará. Belém: Typografia do Diário Oficial, $1^{0}$ de julho de 1892, p. 15. Disponível em: ddsnext.crl.edu/titles/172. Acesso em: 3 nov. 2018.

15 PARÁ. Decreto n. 410 de 8 de outubro de 1891 . Disponível em: https://arisp.files.wordpress.com/2009/07/decreto-estadual-n-c2ba-410-de-8-de-outubro-de-18911.pdf. Acesso em: 3 nov. 2018.

16 Ibidem, p. 4.

17 MUNIZ, João de Palma. Patrimônio dos Conselhos... Op. cit. O Pará possuía à época 51 municípios. Segundo João de Palma Muniz, os municípios paraenses, quando das concessões das áreas que corresponderiam aos seus patrimônios, dividiam-se em: 1) municípios com patrimônios "totalmente discriminados"; 2) municípios "em parte discriminados e parte por discriminar"; 3 ) municípios que "só possuíam concessões", mas ainda não haviam realizado nenhuma discriminação; e, 4) municípios "sem patrimônio requerido". Ibidem, p. 11.

18 MUNIZ, João de Palma. Patrimônio dos Conselhos... Op. cit. p. 9-10. 
da 3a Seção de Agricultura, o engenheiro João de Palma Muniz diria em 1907 que, "Assim como a Nação demarca as suas fronteiras, o Estado traça os seus limites, o Município precisa determinar as suas lindes, como o particular mede e descrimina as suas terras." ${ }^{19}$

Em 1900, a Lei n. 723, promulgada em 2 de abril, determinava que para conceder as terras que fariam parte do seu patrimônio os municípios deveriam cumprir previamente os trabalhos de medição e demarcação de toda a área, considerada para tanto formada por terras devolutas. Grande parte dos conflitos ocorridos no período resulta justamente da sobreposição da concessão de lotes a particulares já ocupados há décadas por famílias de posseiros como decorrência da nova configuração advinda das concessões de terras para a formação dos patrimônios municipais que vinham sendo realizadas desde os anos iniciais da República. De acordo com o artigo $16^{\circ}$ do Decreto de 8 de outubro de 1891, para obtenção do registro de propriedade bastava que o proprietário apresentasse declaração à Repartição de Obras Públicas, Terras e Colonização do Pará para que o órgão os examinasse e encaminhasse sua legitimação, estivessem ou não medidas e demarcadas. As futuras medições e demarcações teriam por base, segundo o Parágrafo Único do art. 70, os registros criados pelo artigo $16^{\circ}$.

No caso das terras havidas por apossamento, os posseiros deveriam apresentar à mesma repartição declaração datada e assinada, relativa ao lote pretendido. Tal declaração deveria conter ainda a situação do lote e o nome pelo qual era conhecido; o município no qual estava situado; a descrição de casa, barracas, currais, e quando houvesse, caminhos de seringueiras, com o número aproximado de pés em estado de corte e quaisquer outras benfeitorias no terreno. ${ }^{20}$ Os posseiros deveriam declarar ainda os limites de seus terrenos, bem como os confrontantes, a existência ou não de "sinais naturais perduráveis" que estivessem dentro da posse, se possuíam agregados e seus respectivos nomes, e o tipo de cultivo a que se dedicava a posse.

Interessante observar dentre as exigências da declaração o item dedicado aos pés e "caminhos de seringueiras". Chamo atenção desse aspecto, pois em grande parte dos conflitos envolvendo posseiros, fazendeiros e comerciantes no período em tela, verificamos que uma das principais motivações para a ampliação das grandes propriedades por via da incorporação de áreas de terras, florestas e matas ocupadas por posseiros residia no desejo de obter tais

\footnotetext{
${ }_{19}$ MUNIZ, João de Palma. Índice Geral do Registro de Terras. Belém: Secretaria de Estado, Obras Públicas, Terras e Viação - Governo Augusto Montenegro, 1907, p. 25. João de Palma Muniz elaboraria ao longo de sua trajetória uma série de estudos sobre legislação municipal, histórias de municípios, coletâneas de legislação agrárias, compilação de registros de terras, dentre outros. Nesse sentido, sua obra se constitui ao mesmo tempo como valiosa fonte de informações e dados sobre os primeiros governos republicanos, principalmente o período Augusto Montenegro (1901-1908), e importante construção de uma memória palaciana dos primeiros anos da República no estado.

${ }^{20}$ O Decreto n. 410, de 8 de outubro de 1891 , criaria o instrumento do "título de posse", instituto jurídico que seria concedido mediante requerimento dos posseiros pelas intendências municipais. Essa atribuição dada às intendências duraria até a promulgação pelo então governador João Antônio Coelho (1909-1913) da Lei n. 1.108, de 6 de novembro de 1909, quando tal concessão passaria para o Governo do Estado. PARÁ. Lei n. 1.108, de 6 de novembro de 1909. Disponível em: https://arisp.files.wordpress.com/2009/08/lei-1108-de1909.pdf. Acesso em: 5 abr. 2019. Para uma discussão sobre títulos de posse no período, ver: TRECCANI, Girolamo. O título de posse e a legitimação de posse como forma de aquisição de propriedade. Revista da Procuradoria Geral do Estado do Pará, Belém, v. 20, p. 121-158, 2009.
} 
terras para a abertura de estradas de seringa e na perspectiva de realizar sua demarcação junto aos órgãos da administração pública, tornando as áreas de exploração da borracha locais de intensos conflitos. Essa questão é de suma importância para compreendermos que as disputas por terra e a expulsão de posseiros de lotes que mantinham e cultivavam há décadas, portanto desde o Império, dava-se, em algumas regiões, no bojo do crescimento do extrativismo e boom da borracha vivido na Amazônia na segunda metade do século XIX e primeiras décadas do século $X X$.

Em suma, o que verificamos em vários municípios do Estado do Pará neste período é um aumento significativo de conflitos de terras oriundos de situações como: sobreposição de concessões de títulos de posse para a mesma área a diferentes posseiros, títulos de posse concedidos a grandes fazendeiros/posseiros e herdeiros de sesmaria em cuja área medida residiam inúmeras famílias de posseiros, dentre outras situações que expuseram uma realidade vigorosamente conflituosa liberando tensões e provocando a reação de várias famílias de pequenos posseiros. O que o estudo de tais casos desvela é a atuação direta das intendências municipais não apenas como instâncias responsáveis pelo registro das posses em áreas que compunham seu patrimônio municipal, mas no envolvimento de não poucos intendentes em registros de posse oriundos de demarcações que se sobrepunham, confundindo limites, opondo posseiros e dando legitimidade a títulos de posse em terras já ocupadas com práticas de morada, agricultura e extrativismo.

Entendemos que a situação de imprecisão quanto aos limites dos lotes havidos por apossamento ante a necessidade de declará-los com vistas a obter os registros junto às intendências, torna o cenário ainda mais fecundo para o desencadeamento de conflitos. Quando atentamos para o fato de que ao conceder terras aos municípios em forma de patrimônio, o Governo estadual o fazia, conforme a legislação, considerando tais áreas como devolutas, podemos inferir que tal atitude significava criar a possibilidade de que as intendências desconsiderassem a ocupação pretérita de inúmeras famílias de posseiros há décadas amanhando parte significativa dessas terras na forma costumeira da "simples posse", sem título algum, a despeito da vigência de Lei de Terras de $1850 .{ }^{21}$ É o que veremos a partir de agora.

\section{Posse da terra e intendências municipais: queixas e denúncias de posseiros nas páginas dos jornais paraenses}

\footnotetext{
${ }^{21}$ Muito embora o Pará seja apontado como uma das Províncias com a maior incidência de registros de terras conforme diretrizes presentes na Lei de Terras de 1850 e no Decreto de 1854, há indubitáveis indícios de que o apossamento continuou ao arrepio da legislação imperial ao longo da segunda metade do século XIX em toda a região, como podemos inferir das leis e decretos aprovados nas primeiras décadas republicanas que irão não só reiterar a legalidade das posses havidas até a data de 15 de novembro de 1889, revisando assim a legislação sobre terras vigente durante o Império, como alargar inúmeras vezes o prazo para o registro e legitimação de posses e sesmarias, que se consideradas à luz da Lei de 1850 já teriam caído em comisso.
} 
Um dos equívocos mais comuns quando se trata de considerar a questão da propriedade num dado período histórico reside na naturalidade com que determinadas concepções teóricas são aprioristicamente formuladas. Tais concepções, via de regra municiadas pelas definições codificadas e formalizadas no âmbito jurídico-institucional, perde de vista, como defende a historiadora catalã Rosa Congost, a necessidade de se atentar para o facticidade das práticas apropriadoras encetadas pelos próprios sujeitos que realizam, na prática, ocupando a terra, acessando os recursos, formas plurais de propriedade que distam quase sempre daquelas presentes nas leis e decretos emanados do Estado. ${ }^{22}$ Ao assumir o caráter plural com que historicamente a propriedade foi realizada, trata-se de considerarmos que quando falamos das ações de apossamento dos sujeitos devemos, segundo Congost, falar em "direitos de propriedade", termo que guarda íntima relação tanto com o caráter de historicidade quanto com o de facticidade com que as práticas proprietárias precisam ser consideradas sem que a perspectiva de pensá-las na sua pluralidade seja prejudicada. ${ }^{23}$

Nos últimos anos têm surgido inúmeras pesquisas que, partindo de uma aproximação com a tradição da história social de matriz thompsoniana e os estudos sobre propriedade e direitos de propriedade de vários autores, como a já referida historiadora Rosa Congost, o jurista italiano Paolo Grossi, o sociólogo português Rui Santos, a historiadora brasileira Márcia Motta, dentre outros, tem se debruçado sobre uma gama variada de períodos e espacialidades, no que tem resultado em um profícuo diálogo na produção de um conjunto de trabalhos que convergem para a realização de uma fecunda História Social da Propriedade no Brasil, buscando refletir sobre formas de propriedade, direitos de acesso, legislação sobre terras e práticas costumeiras de apropriação, abarcando diferentes regiões e temporalidades. ${ }^{24}$

É partindo dessa premissa que podemos observar que a tenaz persistência de posseiros pobres na luta pela permanência em seus lotes e pela continuidade de livre acesso a áreas de extensão de roças, caça, pesca e extração de produtos da floresta, em face da cada vez maior exigência da formalização jurídica do domínio, aponta não somente para as dificuldades de difusão de uma modalidade de ocupação que procurava interromper a cultura do apossamento

22 CONGOST, Rosa. Tierras, leyes, historia: estúdios sobre "La gran obra de la propriedad. Barcelona: Crítica, 2007.

${ }^{23}$ CONGOST, Rosa. Historia, el derecho, e la realidade de la constucciones sociales em la gran obra de la propriedade. História: Debates e Tendencias, Passo Fundo (RS), v. 17, n. 2, p. 374-284, jul.-dez. 2017. Entrevista concedida a Ironita A. Policarpo Machado. Disponível em: http://seer.upf.br/index.php/rhdt/article/view/7500. Acesso em: abr. 2019. Segundo Congost, as práticas de apropriação realizadas pelos sujeitos só podem ser examinadas a partir de estudos empíricos que deem conta da pluralidade com que tais práticas podem ser historicamente realizadas em diferentes contextos. Nesse sentido, para se apreender as definições de direitos de propriedade numa dada época, ao contrário do que dizem códigos, leis e concepções teóricas, faz-se necessário perscrutar as práticas e relações de propriedade experimentadas pelos sujeitos, suas concepções e ações apropriadoras.

${ }^{24}$ GROSSI, Paolo. História da Propriedade e Outros Ensaios. Rio de Janeiro: Renovar, 2006; SANTOS, Rui; ROXO, Maria José. Um conto de duas tragédias: O Baldio da Serra de Mértola no Alentejo (sul de Portugal) e a sua provatização, séculos XVIII a XX. In: MOTTA, Márcia M. M.; PICCOLO, Monica (orgs.). $O$ Domínio de Outrem. Vol. I: Posse e propriedade na Era Moderna (Portugal e Brasil). São Luís; Guimarães, MA: EdUEMA; Nósporcadutobem, 2017. Ver, dentre outros, as coletâneas: MOTTA, Márcia M. M.; SECRETO, Verônica (orgs.). Direito às Avessas: por uma história social da propriedade. Niterói, RJ: EdUFF, 2010; MOTTA, Márcia M. M.; PICCOLO, Monica (orgs.). O Domínio de Outrem. Vol. II: Propriedade e direitos no Brasil. São Luís; Guimarães, MA: EdUEMA; Nósporcadutobem, 2017. 
por famílias de lavradores pobres, mas constituem-se na prova de que os esforços de consolidação da propriedade privada longe de serem o resultado de um percurso natural esbarraram noutras formas de apropriação da terra que demandavam o livre acesso a áreas e recursos bem como na continuidade da autonomia e mobilidade como condição para a (re)produção de formas de vida e trabalho que historicamente articulavam as técnicas possíveis e os recursos disponíveis.

Para realizar a discussão aqui proposta fizemos um levantamento de queixas e denúncias elaboradas por pequenos posseiros e publicadas em diferentes jornais paraenses do período. Tomada tanto como fonte de informação quanto como objeto de estudo, a imprensa e seu uso pela historiografia há muito superou seus estágios iniciais de desconfiança, seja por ser vista como mero "receptáculo de informações a serem selecionadas, extraídas ao bel prazer do pesquisador", seja por inibir os historiadores que partiam do pressuposto de que a imprensa não passava de "mera caixa de ressonância de valores, interesses e discursos ideológicos" da classe dominante. ${ }^{25}$ Vistos hoje sobre ângulos variados, as possibilidades de usos de periódicos impressos ao longo da história do Brasil como documentos históricos tem sido cada vez mais beneficiadas pelo aprimoramento de aportes metodológicos resultantes de uma maior complexidade e aperfeiçoamento da pesquisa em história.

É nesse sentido que os historiadores que se utilizam da imprensa como fonte para as mais variadas pesquisas têm buscado esquadrinhar as páginas impressas sob a orientação de um repertório de indagações que vão desde a atenção para a periodicidade e sua historicidade, tipos de impressão e relações com inovações técnicas e o mercado, presença ou não de iconografia, sua localização no corpo do jornal e vínculos com o texto, até a organização deste em relação aos temas tratados nas páginas do impresso, a análise dos discursos, o termos utilizados nas manchetes de primeira página, bem como os grupos responsáveis e financiadores do jornal, quem escreve, o público destinatário, os meios de divulgação e circulação, quem lê, em suma, quais as representações construídas acerca de determinados setores sociais, etc. Longe de esgotar as possibilidades metodológicas e de problemas de pesquisa, estas seriam algumas perguntas pertinentes ao uso da imprensa pelos historiadores.

Em nossa abordagem procuramos indagar prioritariamente acerca das páginas da imprensa paraense da primeira década da República como lugar frequentado por setores populares que por meio de "cartas, protestos, contraprotestos e abaixo-assinados" dirigidos a autoridades municipais e ao público em geral, fizeram uso dos periódicos como arena de queixas e denúncias, explorando assim, nas brechas abertas pelos jornais, o espaço da imprensa como passível de inscrição da fala dos pobres rurais. Não se trata aqui, contudo, de momentos de revolta que teriam atingido grandes proporções e por isso figurados nos jornais como acontecimentos extraordinários. Ao contrário, trata-se de casos cotidianos que nos permitem inquirir sobre a prática de uma cultura política de protestos protagonizados pelos

25 DE LUCA, Tania Regina. Fontes Impressas: história dos, nos e por meio de periódicos. In: PINSKY, Carla Bassanezi (org.). Fontes Históricas. São Paulo: Contexto, 2006, p. 116. 
pobres rurais que buscavam denunciar o que entendiam como ameaças aos seus direitos de propriedade.

Como noutros estados da recém-proclamada República, a imprensa paraense do período se agrupava em torno de interesses que identificavam seus defensores aos grupos republicanos e monarquistas, ainda que no momento do advento da República no Pará essa clivagem não tenha sido tão radical. Dessa forma, o emblemático periódico $A$ República, criado em 1886 para atuar como espaço de defesa e propagação do ideário republicano pelo Club Republicano do Pará e em torno do qual gravitavam os chamados republicanos históricos paraenses que ocupariam o poder políticos no pós-1889, rivalizaria ao longo dos primeiros governos com jornais alinhados aos monarquistas. Esse era o caso d'O Democrata, periódico originado de outro jornal, O Liberal do Pará, e fundado pelo Partido Republicano Democrático (PRD) a partir da reunião de antigos liberais e conservadores críticos do governo republicano paraense e sobretudo do Partido Republicano do Pará (PRP), e que fazia em suas páginas elogios a "aspectos positivos de medidas ou práticas políticas adotadas por parte dos políticos monarquistas", ainda que não resultasse dessa postura que o PRD estivesse reivindicando o retorno à Monarquia. ${ }^{26}$ Outro periódico que consultamos e que cerrava fileiras, se não em defesa explícita das ideias monarquistas, mas em torno de um espaço de crítica aos governos republicanos no Pará era o Diário de Notícias.

Essas breves considerações sobre a imprensa paraense do período nos ajudam a compreender melhor a recorrência com que denúncias, como a de que pequenos posseiros estariam sendo vítimas de poderosos locais, foram publicadas em O Liberal do Pará no ano de 1889. Da mesma maneira, permite-nos inquirir sobre as denúncias de arbítrios que vinham sendo cometidos por intendentes municipais, agrônomos e juízes, em favor de concessões de títulos de posse a grandes fazendeiros, foreiros influentes e comerciantes nas páginas d'O Democrata. Ambos os jornais, um após o outro, posicionavam-se criticamente em relação aos grupos políticos que capitanearam os primeiros governos republicanos no Pará. Isso explicaria em parte o porquê desses periódicos, pelo que pudemos verificar num primeiro levantamento, juntamente com o Diário de Notícias e O Correio Paraense, manterem uma atenção constante naqueles anos aos conflitos de terras em várias regiões do estado, o que decerto depunha contra a política de terras defendida pelos governos paraenses. Quando visto por outro ângulo, podemos considerar que os pequenos posseiros se aproveitaram dessas disputas entre os chefes políticos locais e se utilizaram do espaço da imprensa para manifestarem suas demandas por direito à terra.

Dentre as principais queixas havia aquelas que apontavam para o envolvimento direto de intendentes municipais na concessão ilegal de registros e títulos de posse resultando de

${ }^{26}$ FARIAS, William Gaia. A República no Pará: os primeiros momentos. In: SARGES, Maria de Nazaré; RICCI, Magda de Oliveira (orgs.). Os oitocentos na Amazônia: política, trabalho e cultura. Belém: Açaí, 2013, p. 189. 
"demarcações clandestinas realizadas em gabinetes" de intendências. ${ }^{27}$ Numa delas, o posseiro Marcelino Dias Pereira, em queixa dirigida "Ao público e ao Intendente da Comarca de Breves", publicada no periódico $O$ Pará em 14 de setembro de 1898, afirmava que,

Pelo costume que este povo adquiriu no município, ou querer abusar da boa-fé dos Intendentes que tem exercido esse cargo, vai o posseiro requerer registro de seu terreno e depois de já estar registrado este, vai qualquer indivíduo, sem ter documentos legais que prove ter aí posse alguma, ilude a boa-fé do sr. Intendente com documentos falsos, fazendo suas divisas dentro de terrenos alheios, e com essas e outras transações tira um outro registro por cima do primeiro, quando a lei das terras não dá esse direito, mas sim o direito ao posseiro que se julgue prejudicado contestar esse registro que prejudica as suas posses (art. 126); d'esta contestação Ihe dará o direito si o tiver, a não fazer segundo registro, e por estes tantos registros que a Intendência faz sair de lugares já registrados sem pedir informações, tem sido o motivo de tantas consequências até de mortes! $!^{28}$

No relato de Marcelino Pereira podemos observar uma prática muito frequente ocorrida em diferentes intendências municipais no período em tela: a sobreposição de concessão de registros de posse como resultado de simples declaração dada ou de ações de medição e demarcação que ignoravam limites entre as posses, seja pela imprecisão dos mesmos, seja pelo deliberado intuito de se apossar das terras alheias. Essa prática disseminava-se por todo o estado em diferentes intendências e revelava as dificuldades em se implantar procedimentos que visassem precisar os limites dos domínios que se convertiam em áreas de disputa.

27 Denúncia realizada pelo lavrador Vicente de Souza Pinto e publicada em: Diário de Notícias, Belém, 14 nov. 1890, p. 3. Disponível em: http://memoria.bn.br/DocReader/763659/9448. Acesso em: 23 jun. 2019.

28 O Pará, Belém, 14 set. 1898, p. 3. Disponível em: http://memoria.bn.br/DocReader/306223/943. Acesso em: 23 jun. 2019. 
Figura 1 - Fragmento de mapa do Estado do Pará (1892), com destaque para as localidades onde ocorreram os conflitos: Município de Breves, Rio Mapuá, no Arquipélago do Marajó e a região de São João de Pirabas e Salinas.

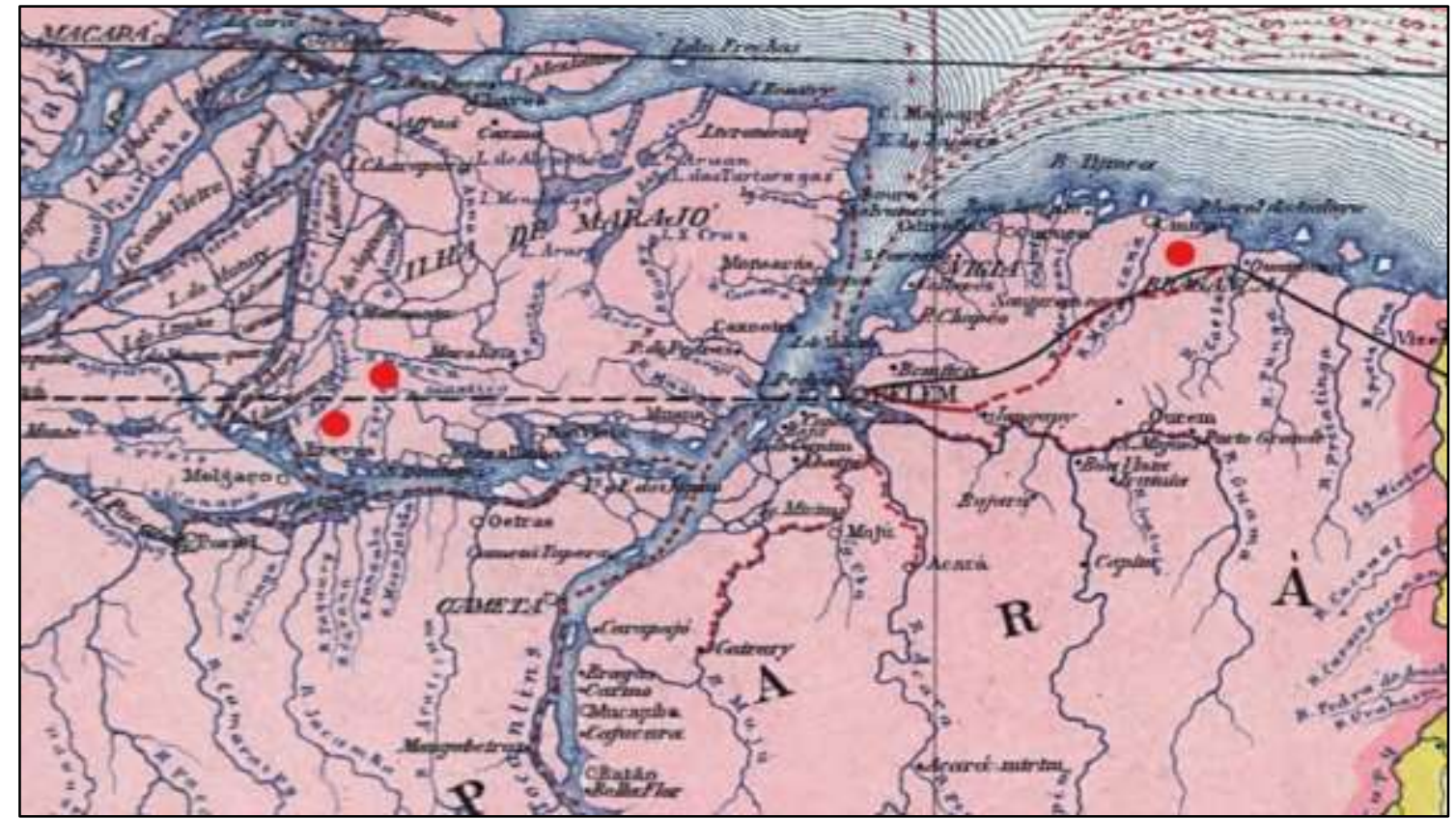

Fonte: Carta dos Estados Unidos do Brazil. (Detalhe). Ministério da Indústria, Viação e Obras Públicas, 1892. Disponível em: https://www.brasil-turismo.com/para/seculo-19.htm. Acesso em: abr. 2019.

Marcelino Pereira denunciava as pretensões de tal Izidoro Portilho em expandir suas terras com vistas a incorporar novas áreas, como intencionava, para a extração do látex. O motivo da denúncia se deu, pois Izidoro teria ultrapassado os limites entre as duas posses, cujo marco era um igarapé, e adentrado em terras de Marcelino. Ainda de acordo com a narrativa de Marcelino, a invasão perpetrada por Izidoro Portilho fora feita à revelia do título de posse já registrado por ele, Marcelino, na Intendência de Breves, ${ }^{29}$ daí a sua revolta contra o que identificava como uma prática ilegal. Ainda que se trate de um caso específico cuja denúncia fora formulada por um único indivíduo, a carta de Marcelino Pereira nos dá valiosas pistas para compreendermos os mecanismos em funcionamento na conformação do espaço rural paraense de fins do século XIX, corroborando com o que temos verificado noutros conflitos em diferentes municípios no mesmo período. Ao indicar a invasão de sua posse, ao que tudo leva a crer, por um grande posseiro, mas com pretensões de expandir seu domínio com vistas ao uso das terras para a atividade extrativa e o comércio da borracha, Marcelino Pereira denuncia prática muito comum no período e que foi largamente utilizada por "patrões" para ampliar ilegalmente seus domínios e áreas de exploração de seringais, como era o caso de muitas regiões no Arquipélago do Marajó.

29 O município de Breves, localizado na "Região das Ilhas", no Arquipélago do Marajó, estava entre aqueles municípios que, embora no período já possuísse concessão de seu patrimônio, ainda não havia realizado a discriminação de suas terras. 
A hipótese que defendemos é a de que as transformações ocorridas no âmbito da organização administrativa do Estado, tanto no que dizia respeito às atribuições dadas às intendências municipais quanto em relação à necessidade de se difundir o princípio da propriedade privada como condição para o desenvolvimento da agricultura, materializados em leis, decretos e políticas correlatas, somados ao crescimento das perspectivas de lucro a serem obtidos com a economia da borracha, promoveram uma generalização dos registros de posses em áreas onde historicamente prevaleceram práticas de ocupação tradicional marcadas pela despreocupação com títulos e a formalização do domínio.

Esse processo punha em risco a continuidade de modalidades costumeiras de acesso a terras e recursos da natureza por posseiros pobres na medida em que se viram cada vez mais preteridos em suas reivindicações por direitos de propriedade em face das pretensões de expansão de grandes fazendeiros e comerciantes. Nota-se que, lidando com uma realidade onde a posse era largamente a modalidade de ocupação predominante, cenário que punha em xeque em fins do século XIX o cumprimento e alcance da Lei de Terras de 1850 na antiga Província, a legislação agrária no Pará republicano não pôde impedi-la, ainda que as ações legais tenham na prática caminhado no sentido de limitá-la em muitos casos à ação dos grandes posseiros. ${ }^{30}$

Já em O Democrata, na edição de 20 de junho de 1890, era publicada carta ao Governador do Estado, Justo Chermont, onde posseiros autodenominados "os pobres" denunciavam que estavam sendo vítimas de violências contra suas posses na localidade do Alto Mapuá, também no município de Breves. Na referida carta, dirigiam-se ao governador para que este tomasse conhecimento dos atos de violência "que se pretendem fazer a propriedade alheia", na expectativa de que o mandatário não fosse "surdo à voz do pobre que apela para o vosso sentimento de justiça". Na denúncia, explicavam que alguns "senhores" pretendiam apossar-se de "terrenos ocupados e cultivados há mais de quarenta anos por legítimos posseiros, que tem nele morada habitual e cultura efetiva". "Os pobres" prosseguiam afirmando que tal de Henrique Joaquim de Almeida conseguira nomeação de um amigo seu para o cargo de juiz comissário do município. Em retribuição, o novo juiz, o tenente coronel Diocleciano Antonio Pinheiro Lobato, teria aberto vários autos de medição e demarcação em nome do amigo, o que fora realizado incluindo as ditas terras ocupadas pelos posseiros.

\footnotetext{
${ }^{30}$ Aqui reside uma questão importante para a qual procuramos aventar uma hipótese. A nova legislação republicana de terras golpeava duplamente o pequeno posseiro: em primeiro lugar, porque embora reconhecendo o direito à posse no caso das terras havidas por ocupação primária, desde que "mansa" e "pacificamente", até a data de 15 de novembro de 1889, prazo que posteriormente seria alargado até 1892, as novas diretrizes jurídicas tendiam, na prática, a consagrar as posses que se acomodassem ao modelo de propriedade individual e produtiva, circunscrita às delimitações que visavam pôr em prática o ordenamento da medição e demarcação, sinais inequívocos de uma tentativa de dar estabilidade e segurança jurídica a um desejado mercado de terras no estado; em segundo lugar, e como decorrência direta da implicação anterior, ao dar prioridade à necessidade da delimitação das posses e propriedades, estabelecendo limites jurídicos para suas extensões, a legislação de terras do Pará buscava impedir a propagação do costume do apossamento por lavradores pobres principalmente no que dizia respeito à práticas costumeiras de usos da terra e dos recursos, práticas combinadas de lavoura e extração que demandavam mobilidade e acesso a áreas "abertas".
} 
Embora na publicação acima não seja possível verificar os nomes dos posseiros que se autodenominavam de "os pobres", uma série de outros protestos e solicitações publicados em anos e jornais diferentes nos permite reconstruir o cenário conflituoso nas terras do Alto Mapuá. Henrique Joaquin de Almeida era comerciante e político influente na localidade do rio Mapuá, 30 distrito do município de Breves, região do Marajó. Acontece que o dito comerciante, como informa notícia publicada no jornal O Liberal do Pará, em 16 de abril de 1889, vinha requerendo as terras situadas no rio Mapuá desde 1885, quando solicitou junto ao então Presidente da Província do Pará a compra de terreno que media cerca de mil e quinhentos a dois metros de frente e quatro mil metros de fundos, em área que apontava como devoluta. ${ }^{31}$

A intenção declarada na ocasião da solicitação de compra das ditas terras era a de utilizar o terreno unicamente para a abertura de estradas de seringal, uma vez que a área era descrita como de terras alagadas e impróprias para a lavoura. Em sua solicitação, Henrique Joaquim de Almeida se utilizava de um estratagema muito comum nessas ocasiões em que se pretendia se apropriar de terras de outrem: com vistas a desqualificar as terras pretendidas, o comerciante apontava-as como inadequadas para o cultivo por se tratarem, segundo informava, de terras alagadas onde nenhuma lavoura se desenvolveria. Contudo, logo ficaria provado que as ditas terras solicitadas como devolutas não apenas estavam ocupadas há muitos anos por inúmeras famílias de posseiros, como eram áreas com cultura efetiva, conforme notava Ofício do secretário da Câmara Municipal de Breves transcrito em O Liberal do Pará nesta mesma edição do jornal. O encaminhamento dado pelo secretário e dirigido ao Presidente da Câmara Municipal de Breves, deu-se no sentido de negar a petição de compra de Henrique Joaquim de Almeida "para não violar direitos que esses antigos posseiros têm adquirido, em virtude da lei de terras e demais regulamentos." ${ }^{32}$

Em julho de 1889, dezenas de posseiros elaboraram um abaixo assinado onde descreviam em detalhes as violências cometidas pela polícia do Pará em favor do comerciante. Citemos trecho do documento, datado de 30 de julho de 1889, e publicado em $O$ Liberal do Pará no mês seguinte, na edição de 24 de agosto. O episódio impressiona pelo grau de arbitrariedade cometida por autoridades policiais e da própria Intendência em defesa dos interesses de Henrique Joaquim de Almeida em obter as terras do Mapuá para a exploração da borracha:

Atestamos nós, abaixo assinados, a quem o conhecimento d'este possa pertencer, que no dia 7 do mês findo, fomos violentamente presos e amarrados e alguns barbaramente torturados, como se fossemos criminosos sentenciados, por 22 praças de polícia do Pará e outros tantos paisanos fregueses de Henrique Joaquim d'Almeida à ordem do subdelegado de polícia do Alto Mapuá, dr. Emílio Dias, a requerimento do dito Henrique e de seu comparsa Lourenço de Mattos Borges [...]. Conduziram-nos ao barracão de Máximo de Miranda de Portugal, na boca do 'Jupaty', aonde permanecemos sempre amarrados até o dia 18 [...]. Na ocasião em que fomos presos dispararam as praças quatro tiros de granadeiras,

310 Liberal do Pará, Belém, 16 abr. 1889, p. 3. Disponível em: http://memoria.bn.br/docreader/704555/21295. Acesso em: 15 maio 2019.

${ }^{32}$ Idem. 
em direção aos fugitivos. Tudo o quanto aqui atestamos é a pura verdade, que juraremos se preciso for. Igarapé-fundo, 30 de julho de $1889 .{ }^{33}$

No município de Gurupá, na localidade de Mumiuba, a lavradora Raymunda Lasaro Ferreira, em Protesto publicado no jornal O Pará na edição de 15 de abril de 1899, denunciava por meio de mensagem datada de 4 do mesmo mês dirigida ao Governador do Estado, o que para ela se caracterizava como uma prática "fraudulenta" de demarcação de terras realizada por um tal engenheiro Salles que teria resultado na expedição de registros de posse em nome de dona Angela Rabelo Mendes Pimentel. Por ser declaradamente analfabeta, não sabendo nem ler nem escrever, a Protestante era a rogo representada por Carlos Lusitano de Castro Berfort. O problema era que o registro expedido compreendia terras que Raymunda Ferreira reivindicava como suas e demais "posseiros pobres" que há muito habitavam aquela região e se ocupavam da agricultura. Segundo a lavradora, não só a demarcação compreendia terras por ela ocupadas, onde mantinha "cultura efetiva e morada habitual", como fora feita pelo engenheiro sem o seu conhecimento, visto que estava ausente no dia e hora em que fora realizada. ${ }^{34}$

Para além da denúncia de que suas terras haviam sido invadidas pelos limites estabelecidos pela demarcação, a protestante ainda denunciava o envolvimento direto do Intendente municipal Maximiano Rabello não só como conhecedor do ato fraudulento, mas como alguém que tinha interesse direto na concessão do novo registro visto que possuía relações de parentesco com dona Angela Rabelo: esta era tia do Intendente municipal. Acusado de "presentear toda sua parentela com os direitos de antigos posseiros pobres, órfãos e viúvas", o Intendente era denunciado como participante de um conluio que ameaçava os "pacatos lavradores" no município. Em defesa dos "posseiros pobres" da localidade de Mumiuba, Carlos Lusitano Belfort, em nome da lavradora Raymunda Ferreira, fazia referência ao art. 65 , §106, da Lei de 5 de setembro de 1892, ao dizer que tal legislação havia garantido e mandado "respeitar as posses adquiridas por ocupação primária, compra, doação, permuta, partilha, arrematação em hasta-pública sujeitando-os a legitimação", situação na qual estaria a posse da protestante. ${ }^{35}$

No apelo final da posseira Raymunda Ferreira, após descrever os limites de sua posse e indicar nela a presença de "pés de seringueiras em idade de corte", o que pode ser forte indício dos reais motivos do avanço sobre suas terras, mais uma vez denuncia a violência que vinha sofrendo com a demarcação e registro de posse concedida com o acordo do Intendente, dizia que ante

33 L Liberal do Pará, Belém, 24 ago. 1889, p. 3. Disponível em: http://memoria.bn.br/DocReader/704555/21707. Acesso em: 20 mar. 2019. Grifos no original.

34 O Pará, Belém, 15 abr. 1899, p. 3. Disponível em: http://memoria.bn.br/DocReader/306223/1630. Acesso em: 25 mar. 2019. Assim como Breves, o município de Gurupá constava entre aqueles que só possuíam concessão de seu patrimônio, mas não realizara sua discriminação.

${ }^{35}$ Idem 
o violento esbulho que tentam fazer de minha posse ao bem estar dos meus parentes, desconheço marco, rumo, e por isso é que chamo a atenção do ilustrado sr. dr. governador do Estado e do digno dr. diretor das obras públicas, para atender a esta reclamação de uma pobre viúva como sou, tendo a meu cargo netas, sobrinhas e sobrinhos, pois, querem extorquir dos meus direitos. ${ }^{36}$

Vejamos um último caso de conflito que sintetiza significativamente as questões até aqui levantadas. Ocorreu no distrito de São João de Pirabas, pertencente à época ao município de Salinas, área localizada na região do Salgado. ${ }^{37}$ Trata-se de um "Protesto" da sra. Mariana Tibúrcio de Mattos Muniz publicado no jornal Folha do Norte em 1896. O jornal A Folha do Norte atuou nos primeiros anos da República no Pará, juntamente com o já citado periódico do PRP A República, como um dos principais veículos de defesa dos ideais republicanos no estado, ainda que reivindicasse ser um órgão "absolutamente imparcial". ${ }^{38}$ Criado nesse mesmo ano por Cipriano Santos e Enéas Martins, o periódico constituía-se num dos principais apoiadores do então governador Lauro Sodré, condição que conservaria nos anos seguintes mesmo quando o ex-governador fundasse o Partido Republicano Federal (1898) e pouco tempo depois rompesse com o Partido Republicano do Pará que ajudara a criar.

Não seria por acaso, portanto, que $A$ Folha do Norte publicasse o protesto da sra. Mariana Tibúrcio, dando amplo espaço para que a protestante defendesse sua versão na querela de que herdara de Francisco Bernardino Muniz, marido já falecido, e de seu sogro, Joaquim de Figueiredo Muniz, antigo sesmeiro, as terras que pleiteava como "senhora e possuidora". Tratava-se de área reivindicada como formada por antiga sesmaria que perfazia, segundo seu protesto, légua e meia de fundos e duas de frente, estendendo-se do Rio Pirabas ao Rio Axindeua. ${ }^{39}$

Consta no "Protesto" de Mariana Tibúrcio que a Intendência de Salinas teria concedido indevidamente inúmeros títulos provisórios de posse para famílias de posseiros ocupantes de terras que pertenciam ao seu domínio e que poderiam ser comprovadas pela carta de sesmaria

36 O Pará, Belém, 15 abr. 1899, p. 3. Disponível em: http://memoria.bn.br/DocReader/306223/1630. Acesso em: 25 mar. 2019.

37 O município de Salinas, tendo obtido concessão de seu patrimônio pelo Dec. n. 1247 de 23 de setembro de 1903, não havia, até 1904, discriminado seu patrimônio, estando entre aqueles municípios que só possuíam a concessão. Note-se, no entanto, que à época do referido conflito, o município não havia ainda obtido a concessão de sua área patrimonial.

${ }^{38}$ Ao contrário de outros jornais do mesmo período, que se identificavam como órgãos políticos e via de regra vinculados a partidos, a Folha do Norte trazia logo em sua primeira página o seguinte dizer: "Absolutamente imparcial, a FOLHA DO NORTE recebe e publica todos e quaisquer artigos, notícias e informações, contanto que lançados em termos convenientes." Uma visão geral do papel da Folha do Norte nas primeiras décadas da República no Pará com especial atenção para publicações nas páginas do jornal sobre temas relacionados a migração de trabalhadores para os núcleos coloniais, ver o trabalho já citado em: LACERDA, Franciane Gama. Migrantes cearenses no... Op. cit.

39 Folha do Norte, Belém, 18 abr. 1896, p. 3. Disponível em: http://memoria.bn.br/DocReader/101575/425. Acesso em: 25 ago. 2018. Segundo carta de sesmaria concedida em nome de Joaquim de Figueiredo Moniz e datada de 14 de março de 1821, o correto seria légua e meia de testada e duas de fundo. Registro de Carta de Data Sesmarias passada a Joaquim Figueiredo Moniz. Coleção ITERPA Sesmarias, Livro 20; doc. 148, fl. 112. Disponível em: http://www.rosepepe.com.br/hotsite_acervo/sesmarias/. Acesso em: 25 ago. 2018. Pudemos conferir o documento por meio de pesquisa por nós realizada junto ao acervo digitalizado e transcrito pelo Instituto de Terras do Pará por meio da Coleção ITERPA de Sesmarias (1721-1824), trabalho feito a partir dos Livros de Registros de Datas e Sesmarias que se encontram sob guarda do Arquivo Público do Pará. 
de seu pai e título concedido pela mesma Intendência. A protestante informava ainda que os limites das ditas terras tinham sido reconhecidos por engenheiro competente e seus marcos reavivados pelo mesmo quando da ocasião da elaboração do referido "Protesto": "é mais uma justificativa de que sou possuidora realmente, por títulos legais desse lote de terras que atravessa os fios da linha telegráfica, que vão ter à vila de Salinas, cujo trabalho veio esclarecer mais essa posse. ${ }^{\prime 40}$

Mariana Tibúrcio protestava contra famílias de posseiros considerados invasores de seus domínios em terras que segundo ela foram demarcadas primeiramente a pedido de Joaquim de Figueiredo Muniz no ano de 1823, tendo obtido a aprovação já no ano seguinte. De acordo com a autora, a mesma área teria sido reconhecida pela Repartição de Terras, Obras Públicas e Viação em 1835, segundo consta do primeiro registro de terras da agência provincial. Ainda segundo a Sra. Maria Tibúrcio de Mattos Muniz, as terras legadas em sesmarias constavam de registro feito pela mesma no livro da Intendência Municipal de Salinas, (segundo a protestante, nas fls. 18 e 33), no que contava com informação confirmada pelo Secretário do município, o Sr. Sarmanho Netto.

Notícia publicada no jornal Folha do Norte, em 18 de abril de 1896, dava conta de que Mariana Tibúrcio, em declaração data do dia 15, dava 30 dias, a contar da data de $1^{0}$ de maio, para que os posseiros deixassem as terras que estariam ocupando ilegalmente. A declaração continuava afirmando que os posseiros haviam recebido da Intendência de Salinas títulos provisórios sem qualquer validade perante a comprovação de que as terras compreendiam áreas de sesmaria legada pela família do falecido marido de Mariana Tibúrcio. Tratava-se, portanto, de concessão de títulos de posse a posseiros que careciam ainda de confirmação, o que somente poderiam ser obtidos mediante medição e demarcação, conforme estava previsto no regulamento estadual de terras e competia à Intendência observar.

As disputas das terras do Axindeua, contudo, prolongaram-se pelos anos seguintes. Em março de 1899, três anos após o primeiro protesto de Marina Tibúrcio, famílias de lavradores que se autodenominavam de "moradores e posseiros" publicaram no periódico O Pará um "abaixo-assinado" em forma de "contraprotesto" onde expunham a defesa do direito de permanecerem nas referidas terras uma vez que estas não estariam dentro dos limites declarados por Mariana Tibúrcio. Segundo o documento:

Nós, abaixo-assinados, moradores e posseiros de terras registradas no rio Axindeua, município de Salinas, tendo deparado na Folha do Norte [...], com um protesto de dona Mariana Tibúrcio de Mattos Muniz, assinado pelo seu procurador Manuel Castelo Branco, publicação essa que visa diretamente a nós e

\footnotetext{
40 Ao que parece, o termo "posse", utilizado pela protestante, não tem o mesmo significado que para os posseiros deste e dos outros casos que tratamos anteriormente. Por se tratar de herdeira de sesmaria e, portanto, de forma de apropriação distinta do apossamento, inferimos que o significado aqui se aproxima do de "possuidora" ou dona, o que a torna mais identificada à noção de proprietária, termo que inclusive fará uso, como o de "propriedade", no mesmo protesto. Para um exemplo de discussão sobre a ambiguidade e imprecisão de termos utilizados para designar distintas formas de apropriação da terra noutra região, ver: SILVA, Francisco Carlos Teixeira da. A Formação Social da Miséria: Porto da Folha no Sertão do São Francisco (1820-1920). Rio de Janeiro: Autografia, 2018. (Especialmente Parte I, capítulo II, p. 53-79).
} 
na qual a sua autora diz que estamos dentro do perímetro, das terras de sua propriedade, sem permissão sua ou de alguém por si autorizada, declaramos formal e terminantemente ser falsa tal afirmativa, pois estamos em terrenos por lei e por direito de nossas propriedades e não dentro da área de sesmaria que essa senhora diz possuir nesse município, como vamos provar com factos absolutamente incontestáveis e que nos dão os direitos consagrados nas leis das terras em vigor. ${ }^{41}$

O abaixo-assinado prossegue afirmando que a maioria das famílias que ocupava as terras em litígio era de posseiros "desde muito antes de 1854, quando entrou em execução a liberal lei que dava direto fácil de cada posseiro declarar a sua posse", e que tendo já de longa data declarado as ditas posses, nunca encontraram qualquer oposição do Sr. Francisco Bernardino Muniz, marido falecido de dona Mariana Tibúrcio, que em momento algum teria feito protesto à ação dos posseiros. Segundo os posseiros, o falecido marido de dona Mariana Muniz não só não se opusera às posses como teria mantido com os posseiros ao longo dos anos as "mais inalteráveis relações de amizades", tendo até mesmo comprado e vendido terras em negócios feitos com posseiros antigos e novos ocupantes.

Para os posseiros havia uma clara intenção de esbulho por parte de Mariana Tibúrcio de terras para as quais foram obtidos junto à Intendência de Salinas títulos legítimos que eram utilizados como prova de legítima ocupação. A denúncia era de que Mariana Tibúrcio pretendia expulsar os posseiros das terras que alegava serem suas para aproveitar-se de áreas já beneficiada. Na defesa dos posseiros, portanto, a terras pertencentes à sesmaria de dona Mariana Tibúrcio não chegavam até o povoado onde estavam localizadas suas posses, pois, segundo apontavam, as mesmas findavam nos limites do igarapé Ubussú, afluente do rio Axindeua, muito aquém das terras onde mantinham suas posses. Os posseiros alegavam que, ao contrário do que afirmava dona Mariana, os antigos marcos demarcatórios não foram reavivados, mas, ao contrário, tendo já desaparecidos, foram erguidos novos marcos a partir de novas medições que visavam atender aos interesses da protestante.

Infelizmente não pudemos conhecer, até agora, o "desfecho" desta e das outras querelas abordadas. Todavia, entendemos que por se tratar de uma proposta de investigação que busca compreender disputas por terra que por meio da ação de posseiros mobilizaram diferentes práticas e concepções acerca de direitos de propriedade em face de sua formalização jurídicoestatal, nossos objetivos se orientam menos pelo alcance de um suposto "vencedor" ou "verdadeiro proprietário" segundo critérios estatistas, do que em desenredar o transcurso dos conflitos, razão pela qual nos detivemos aqui nas dinâmicas e relações dos sujeitos em disputa.

\section{Considerações finais}

${ }^{41}$ O Pará, Belém, 8 mar. 1899, p. 3. Disponível em: http://memoria.bn.br/DocReader/306223/1513. Acesso em: 25 ago. 2018. 
Os casos acima citados, selecionados aqui dentre tantos outros para demonstrar os vínculos entre os conflitos de terras e as intendências municipais nas primeiras décadas de governos republicanos no Pará, aproximam-se quando não pelo envolvimento direto de posseiros em defesa da permanência em posses nas quais habitavam e cultivavam há décadas, também por exporem distintas concepções de direitos de uso da terra e práticas de propriedade em face de regulamentos estaduais que ambiguamente reconheciam o direito de posseiros, ao mesmo tempo em que dificultavam sua realização face à pressão exercida pelo avanço sobre terras ocupadas por fazendeiros e comerciantes em âmbito local.

Como pudemos verificar, há inúmeros casos de denúncias de posseiros que estariam sendo ameaçados, seja coercitivamente por policiais, seja pela interferência direta de intendentes municipais em favor de parentes, poderosos e políticos locais. Um número significativo desses casos, a exceção aqui é o último conflito analisado, ocorre devido a pretensões de grandes comerciantes e fazendeiros em adquirir terras para o cultivo e exploração do látex. Pelos conflitos daí desencadeados e as denúncias de posseiros presentes nas páginas de vários jornais paraenses no período podemos afirmar que tais áreas, longe de se constituírem em áreas devolutas, estavam há décadas ocupadas e cultivadas por famílias de posseiros.

Um fator de extrema relevância a ser aqui destacado e que nos ajuda a compreender o acirramento das disputas envolvendo pequenos posseiros durante os primeiros governos republicanos implica em observar que o período de auge da economia gomífera se dá num cenário onde, ao contrário da fase inicial caracterizada pela pouca preocupação com a regularização das posses, ${ }^{42}$ há uma verdadeira corrida pela obtenção de títulos de posse e aquisição de terra, seja por compra, seja pela simples expansão dos limites das propriedades, o que ocorre em consonância com os esforços dos governos paraenses em formalizar a propriedade privada da terra. Nesse sentido, em síntese, acreditamos que o acirramento dos conflitos de terras no período em algumas localidades do Pará está relacionado tanto à conjuntura de expansão das áreas para a exploração de seringais entre fins do século XIX e início do XX, quanto das mudanças na legislação sobre e terras e das novas atribuições dadas aos municípios como resultado da instauração do regime republicano.

\footnotetext{
42 OLIVEIRA FILHO, João Pacheco de. O caboclo e o brabo. Notas sobre duas modalidades de força-detrabalho na expansão da fronteira amazônica no século XIX. In: SILVEIRA, E. (org.). Encontros com a Civilização Brasileira. Rio de Janeiro: Civilização Brasileira, 1979, p. 101-140. (n. 11).
} 


\section{Referências}

ARRUDA, Pedro Fassoni. Capitalismo dependente e relações de poder no Brasil: 1889-1930. São Paulo: Expressão Popular, 2012.

CONGOST, Rosa. Tierras, leyes, historia: estúdios sobre "La gran obra de la propriedad." Barcelona: Crítica, 2007.

CONGOST, Rosa. Historia, el derecho, e la realidade de la constucciones sociales em la gran obra de la propriedade. História: Debates e Tendencias, Passo Fundo (RS), v. 17, n. 2, p. 374-284, jul.-dez. 2017. Entrevista concedida a Ironita A. Policarpo Machado. Disponível em: http://seer.upf.br/index.php/rhdt/article/view/7500. Acesso em: abr. 2019.

DE LUCA, Tania Regina. Fontes Impressas: história dos, nos e por meio de periódicos. In: PINSKY, Carla Bassanezi (org.). Fontes Históricas. São Paulo: Contexto, 2006.

DOLHNIKOFF, Miriam. O pacto imperial: origens do federalismo no Brasil do Século XIX. São Paulo: Globo, 2005.

FARIAS, William Gaia. A República no Pará: os primeiros momentos. In: SARGES, Maria de Nazaré; RICCI, Magda de Oliveira (orgs.). Os oitocentos na Amazônia: política, trabalho e cultura. Belém: Açaí, 2013.

GROSSI, Paolo. História da Propriedade e Outros Ensaios. Rio de Janeiro: Renovar, 2006.

LACERDA, Franciane Gama. Migrantes cearenses no Pará: faces da sobrevivência (1889-1916). Belém: Açaí, 2010.

LEAL, Vitor Nunes. Coronelismo, enxada e voto. O município e o regime representativo no Brasil. São Paulo: Companhia das Letras, 2012.

MOTTA, Márcia M. M.; MENDONÇA, Sônia Regina de. Continuidade nas rupturas: legislação agrária e trabalhadores rurais no Brasil de inícios da República. Revista Brasiliense de Pósgraduação em Ciências Sociais, Brasília, v. VI, p. 127-147, 2002.

MOTTA, Márcia M. M.; SECRETO, Verônica (orgs.). Direito às Avessas: por uma história social da propriedade. Niterói, RJ: EdUFF, 2010.

MOTTA, Márcia M. M.; PICCOLO, Monica (orgs.). O Domínio de Outrem. Vol. I: Posse e propriedade na Era Moderna (Portugal e Brasil). São Luís; Guimarães, MA: ed. UEMA; Nósporcadutobem, 2017.

MOTTA, Márcia M. M.; PICCOLO, Monica (orgs.). O Domínio de Outrem. Vol. II: Propriedade e direitos no Brasil. São Luís; Guimarães, MA: EdUEMA; Nósporcadutobem, 2017.

MUNIZ, João de Palma. Patrimônio dos Conselhos Municipais do Estado do Pará. Paris: Aillaud \& Cia., 1904.

MUNIZ, João de Palma. Índice Geral do Registro de Terras. Belém: Secretaria de Estado, Obras Públicas, Terras e Viação - Governo Augusto Montenegro, 1907.

MUNIZ, João de Palma. Legislação de Terras: dados estatísticos. Pará: Instituto Lauro Sodré, 1924.

NUNES, Francivaldo Alves. Terras de Colonização: agricultura e vida rural ao Norte do Império brasileiro. São Paulo: Scortecci, 2016. 
OLIVEIRA FILHO, João Pacheco de. O caboclo e o brabo. Notas sobre duas modalidades de força-de-trabalho na expansão da fronteira amazônica no século XIX. In: SILVEIRA, E. (org.). Encontros com a Civilização Brasileira. Rio de Janeiro: Civilização Brasileira, 1979.

SANTIN, Janaína Rigo; RODIGHERI, Bruno Nogueira. O poder local na federação brasileira. Argumenta Journal Law, Jacarezinho (PR), n. 25, p. 275-299, jul.-dez. 2016.

SANTOS, Francisnaldo Souza dos. Ações colonizadoras em descompasso: legislação, propaganda e atuação de colonos estrangeiros nos últimos anos do Império e início da República. 2016. Dissertação (Mestrado em História Social da Amazônia) - Faculdade de História, Universidade Federal do Pará, Belém.

SANTOS, Rui; ROXO, Maria José. Um conto de duas tragédias: O Baldio da Serra de Mértola no Alentejo (sul de Portugal) e a sua provatização, séculos XVIII a XX. In: MOTTA, Márcia M. M.; PICCOLO, Monica (orgs.). O Domínio de Outrem. Vol. I: Posse e propriedade na Era Moderna (Portugal e Brasil). São Luís; Guimarães, MA: EdUEMA; Nósporcadutobem, 2017.

SILVA, Francisco Carlos Teixeira da. A Formação Social da Miséria: Porto da Folha no Sertão do São Francisco (1820-1920). Rio de Janeiro: Autografia, 2018.

TERRA, Paulo Cruz; MAGALHÃES, Marcelo de Souza; ABREU, Martha (orgs.). Os poderes municipais e a cidade: Império e República. Rio de Janeiro: Mauad X, 2019.

TRECCANI, Girolamo Domenico. O título de posse e a legitimação de posse como formas de aquisição de propriedade. Revista da Procuradoria Geral do Estado do Pará, Belém, v. 20, p. 121-158, 2009. 